\title{
Skolen der ikke stopper med ikke at etablere sig
}

Hvad der udadtil kendes som 'den slovenske skole', hedder indadtil, i Slovenien, Selskabet for Teoretisk Psykoanalyse. ${ }^{1}$ Det er af flere grunde meget sjældent, at nogen i Slovenien bruger betegnelsen 'den slovenske skole', mest måske fordi det ville virke underligt ekskluderende at tilskrive en gruppe af tænkere en særlig status som den slovenske skole, mens andre tænkere i samme land, der ikke tilhører den samme grundlæggende filosofiske orientering, ville blive reduceret til... ja, hvad? Enten nogen, der tilhører en anden skole, som altså ikke kan være slovensk (den tyske, franske, engelske?), hvilket geografisk ville virke temmelig besynderligt, eller nogen, der simpelthen ikke er kvalificeret til at blive optaget i den slovenske skole. De, der tilhører (det, vi kalder) den slovenske skole, vil altså som regel ikke gøre sig til af at tilhøre den, men snarere i stedet henvise til Selskabet for Teoretisk Psykoanalyse og dets to væsentligste aktiver: bogserien ANALECTA og tidsskriftet Problemi. En foreløbig, og ikke helt urimelig definition af det, vi kalder for den slovenske skole, ville derfor egentlig være følgende: Hvis man tilhører den slovenske skole, betegner man sjældent sig selv som sådan, og man publicerer i Problemi. Lad os i første omgang kalde dette en nødvendig, men ikke tilstrækkelig betingelse.

\section{Forhistorien}

Problemi blev oprindelig grundlagt i 1961 af Den Socialistiske Ungdomsliga og overtaget af Selskabet for Teoretisk Psykoanalyse (STP) i starten af 1980erne. STP selv blev etableret i 1981 af filosoffer som Rastko Močnik, Slavoj Žižek, Rado Riha og Mladen Dolar, med henblik på at arrangere konferencer, muliggøre udvekslinger og etablere bogudgivelser omkring de emner, der optog dem. Det handlede om en organiseret læsning og anvendelse af den franske strukturalisme, herunder Jacques Lacan, til at analysere både filosofiske og kulturelle problemer. Men STP var samtidig en prag- 
matisk nødvendighed - en måde at finde en formaliseret legitimering af de interesser, gruppens medlemmer havde opdyrket gennem det seneste årti. Det var selskabets egentlige anstødssten. For overhovedet at have lov til at arrangere konferencer etc. måtte STP nemlig godkendes som en forening af de allerede eksisterende lignende foreninger, dvs. filosofiske, sociologiske og psykologiske selskaber, og af den jugoslaviske stat. Det kan allerede virke bizart for en nutidig, europæisk læser, men selve det at beskæftige sig med den franske strukturalisme (Derrida, Foucault, Althusser, Lacan) var rent faktisk politisk suspekt i 1970ernes Jugoslavien, og det var derfor noget af en balancegang at finde en modus vivendi, der tillod en seriøs beskæftigelse med den. Det mest markante udtryk for dette problem var afvisningen af Slavoj Žižeks specialeafhandling, som ifølge bedømmelsen ikke var i overensstemmelse med den marxistiske tænkning. Rent bortset fra at dette naturligvis var en klokkeklar politisk tilsidesættelse af en ung tænker, som allerede var bredt anerkendt som yderst talentfuld, var det også udtryk for et egentligt filosofisk sammenstød, idet afhandlingen præsenterede en helt anden måde at læse den hegelianske og marxistiske arv end den, der var kendt og etableret i Jugoslavien. I forskellige udformninger var det en humanistisk antistalinistisk marxisme, der var den fremherskende, og den mest etablerede kritiske skole var Praxis-gruppen i Zagreb, der tog udgangspunkt i den tidlige Marx og spørgsmål om bl.a. fremmedgørelse og en mere åben realisering af den socialistiske debat i Østeuropa. Frankfurterskolen var desuden en vigtig inspirationskilde og diskussionspartner for de fleste filosofiske og politiske tænkere, mens det, der foregik i Paris, groft sagt blev ignoreret eller betragtet med stor skepsis. (Afvisningen af afhandlingen fik i øvrigt i første omgang ret store konsekvenser for Žižek, der ikke fik det job som underviser på universitetet, han ellers var blevet stillet i udsigt, men i stedet måtte gå arbejdsløs i flere år).

Skal man forstå, hvad den 'slovenske skole' betyder, skal man, ifølge Mladen Dolar, derfor faktisk helt tilbage til 1971, hvor slovenske publikationer begyndte at dukke op, i første omgang fra Rastko Močnik og siden Slavoj Žižek og Dolar (født i henholdsvis 1944, 1949 og 1951), der bragte de nye franske tænkere i anvendelse i forståelsen af, hvad der var på færde i verden. Det var her, en generationsbestemmende ændring af, hvad det kunne betyde at være marxistisk tænker, blev indledt. Ungdomsoprøret, borgerrettighedsbevægelsen i USA, Che Guevara, Woodstock osv. var ikke bare et vesteuropæisk, antiautoritært opbrud, men et opbrud, der også havde genklang i Østeuropa og måtte læses sammen med f.eks. Foråret i Prag. De unge slovenere havde en fornemmelse af, at noget var på færde, som var 'større' end det, der 
var blevet beskrevet i den humanistiske marxisme, og de søgte en forståelsesramme i den franske strukturalisme. I den forstand var der faktisk ikke tale om et eksplicit politisk projekt, men langt snarere en filosofisk intuition om, at noget var på færde i Frankrig, som betød et nybrud i forhold til helt grundlæggende filosofiske problemstillinger, inklusive politiske. Verden var i opbrud, og det virkede kun rimeligt, at den filosofiske verden også måtte være det.

Men hvori bestod så den filosofiske forskel til de eksisterende skoler? På en måde skulle man trække hele den franske strukturalisme op over for Frankfurterskolen og Praxis-skolen for at besvare dette spørgsmål, men et centralt spørgsmål var spørgsmålet om, hvordan mennesket skulle forstås i forhold til dets sociale og politiske sammenhænge, om det kunne 'forenes med disse' og fremstå helt og harmonisk, eller om menneskelig subjektivitet grundlæggende set langt mere handler om en afstand, en mangel, en ufuldstændighed, der ikke kan ophæves eller forsones gennem socialiteten. På mange måder handler dette om helt forskellige læsninger af Hegel: Er der en 'objektiv ånd', nu eller i fremtiden, en socialitet og en anerkendelsessfære, hvor mennesket overvinder sin materielle og sociale fremmedgørelse, eller er manglen og selvmodsigelsen konstitutiv i en langt mere radikal forstand, således at det, man groft sagt kan gøre sig håb om, er at leve med sin mangel på en fornuftig måde...? Mladen Dolar forklarer:

En simpel skillelinje løb ved humanisme-antihumanisme-fronten, hvor den udtalte antihumanistiske linje, som strukturalismen stod for, blev set som syndefaldet af både Frankfurter- og Praxis-folkene. Langs denne linje delte også spørgsmålet om dialektik og den hegelianske arv vandene. [...] Vi [dvs. de unge slovenere, HJB] tænkte alle, at dette var det revolutionære moment, og vi drog den konklusion, at de nye antihumanistiske måder at håndtere spørgsmålet om subjektet på var mere produktive end den snak, der handlede om fremmedgørelse og reappropriering.

Antihumanismen består i ikke at se mennesket som et principielt harmonisk og selvberoende væsen, der 'blot' er blevet forstyrret af ulige magtforhold, fremmedgørende produktionsforhold og livsomstændigheder, relation til naturen osv. Antihumanismen handler om, at fremmedheden er indskrevet i mennesket selv; at det er dét, der gør det til menneske. Det, der forenede de mange begivenheder og strømninger i slutningen af 1960erne og starten af 1970erne, var derfor for de unge slovenere ikke en fælles snarlig realisering af et humanistisk ideal om mindre fremmedgørelse, mere åbenhed og 
anerkendelse og tolerance, men snarere en fællesmenneskelig fremmedhed over for enhver politisk-filosofisk doktrin om, hvordan samfundet bedst tilgodeser vores behov: nationalistisk, fascistisk, marxistisk, humanistisk, liberalistisk... Ambitionen var først og fremmest filosofisk, men uundgåeligt vævet sammen med de politiske begivenheder. Kunne man læse Hegel med Lacan i stedet for med Lukács? Kunne man tænke forskel og mangel, Derrida og Lacan, som mere fundamentale end et bestemt menneskeligt potentiale til virkeliggørelse af visse evner og behov? Og hvad ville det betyde for, hvilke forandringer man kunne håbe på? "Vi var overbeviste om," som Dolar siger, "at den politiske effekt af den 'strukturelle revolution' var mere vidtrækkende, om end også noget vanskeligere at kortlægge”. Det var først i slutningen af 1970 erne, at Lacan blev den helt centrale figur i denne kortlægning og først i slutningen af 1980erne, at det blev klart, at den havde noget for sig, for alvor, som skabte en helt ny måde at bedrive filosofi på, en måde, der gjorde sig fortjent til i manges øjne at blive kaldt 'en skole'.

\section{Dåben}

Det var således ikke helt uden rimelighed, at det var den argentinske filosof Ernesto Laclau, der i slutningen af 1980erne navngav 'den slovenske skole' som en ny og vibrerende forsamling af tænkere, der kunne betragtes som en del af Laclaus eget radikalt-demokratiske projekt, der skulle forny venstrefløjstænkningen i epoken efter opgøret med det 20. århundredes totalitære regimer. I bogen Hegemony and Socialist Strategy fra 1985 havde Laclau sammen med den belgiske filosof Chantal Mouffe udarbejdet et (delvist selv-)opgør med den marxistiske tradition og dens efter deres mening for ensidige fokusering på økonomiens betydning for enhver samfundsmæssig og teoretisk udvikling. Noget var gået alvorligt galt i det tyvende århundredes såkaldte 'reelt eksisterende socialisme', og én måde at udlægge Laclau og Mouffes analyse af dette ville være at fremhæve, hvordan demokratiske kampe, efter deres mening, aldrig kan reduceres til én grundlæggende forklaring af ulighed og uretfærdighed, én løsning på samfundets problem, sådan som marxismen havde haft for vane, men tværtimod bestandig må kæmpes på mangfoldige fronter uden at skabe endegyldige 'suturer' mellem alle dets elementer.

Laclau og Mouffes projekt var først og fremmest antiessentialistisk, og på denne måde fandt de oplagte samtalepartnere i de unge slovenske tænkere, der som beskrevet netop brød med de former for tænkning, der insi- 
sterede på en (humanistisk) essens, som samfundet i større eller mindre grad indfriede. Ideologi betød for radikaldemokraterne netop en fornægtelse af 'umuligheden af en endegyldig sutur', dvs. opfattelsen af, at samfundet kan forklares og befæstes ud fra ét perspektiv, om det så er økonomien, nationen, Gud, eller noget helt fjerde. Demokratiske kampe handler om at åbne og mangfoldiggøre perspektiverne, og kritik om at analysere undertrykkelse og udnyttelse på hvert enkelt område for sig, selvfølgelig med bevidstheden om tværgående indflydelse og overdeterminerende begreber og diskurser (hvis 'økologi' bliver ekstremt vigtig, får det uundgåeligt indvirkning på, hvordan vi tænker andre problemer som økonomi, transport osv.), men aldrig ud fra én grundlæggende synsvinkel, som alle problemer kan reduceres til. Måske er 'lesbisk kamp' faktisk ikke 'klassekamp', som det ellers hed i 1970erne.

Laclau havde først og fremmest haft kontakt med Žižek, hvis arbejde han beundrede og betragtede som et vigtigt bidrag til genopfindelsen af et nyt venstreorienteret demokratiprojekt. Žižeks første internationale bog, The Sublime Object of Ideology fra 1989, kom da nærmest også som kaldet til den opgave med sin fremhævelse af det liberale demokrati som en måde at institutionalisere umuligheden af at symbolisere det Reelle på, dvs. som en vedvarende åbning i hjertet af den politiske magt, bedst udtrykt ved valghandlingen, hvor magten så at sige evakueres, og ingen principielt kan sige, hvad der følger. Det system med liberalt-demokratiske principper og en form for reguleret markedsøkonomi, som de østeuropæiske stater i årene efter Murens fald indskrev sig i, var muligvis, som Žižek dengang yndede at sige det, 'det værste af alle mulige systemer'. Problemet var bare, at det havde vist sig, at alle andre var verre... Derfor stillede han endda op til præsidentvalget i Slovenien i 1990 for de Liberale Demokrater, der var en slags venstreorienterede med et meget stærkt fokus på forandring og nybrud, hvilket var i fin tråd med Laclaus opfattelse af, hvilke muligheder situationen gav. "Vi må holde op med at leve andres drømme", som Žižek sagde under debatarrangementerne op til valget med en klar henvisning til debatten om Jugoslaviens enhed og i det hele taget den 'reelt eksisterende socialismes' fejlslagne marxistiske projekt. (Samme overskrift skulle han senere komme til at give bl.a. Europas forhold til USA).

The Sublime Object of Ideology blev startskuddet til en hel række af bøger inden for de (indtil videre) næste 20 år, hvor Žižek udviklede sin teori om ideologikritik, men også vedvarende uddybede sit tag på psykoanalysen og den klassiske tyske filosofi. De mange politiske analyser, der efterhånden løbende blev offentliggjort i førende internationale aviser, var hele tiden ind- 
rammet af en vedvarende udforskning af forholdet mellem den tyske idealisme og Lacans psykoanalytiske teori. Gradvist, og ikke uden indflydelse fra kollegerne i Ljubljana, blev også ideologiteorien omformet, ikke mindst i en delvist ændret forståelse af Lacans begreb om det 'reelle'. Hvis det reelle i starten var manglen, fraværet, umuligheden af en fuldstændig beskrivelse og en harmonisk samfundsstruktur, blev det senere til det, som bryder ind gennem ordenens revner og mangler og skaber muligheden for en helt ny forståelse og omkalfatring af ordenen selv.

Alenka Zupančič' beskrivelse af 'det reelles etik' i hendes bog om Kant og Lacan fra 2000 har uden tvivl været en del af denne inspiration, ligesom Alain Badious begreb om "begivenheden” satte sit præg på Žižek. Det reelle blev til det, der ikke kan ske, men alligevel sker. Det, at ordenen falder, fordi der er noget helt uhørt og uventet, der sætter sig igennem, sker, finder sted. Denne teoretiske forandring havde igen politiske konsekvenser. Hvor det reelle før, som beskrevet, var enhver ordens inhærente umulighed, blev det nu til ordenens knude på sig selv, indbruddet, omvæltningen. Således ændredes Žižeks politiske standpunkt sig, hvis man overhovedet kan sige, at han i streng forstand har haft et, til en interesse for de punkter i historien, hvor sådanne radikale brud har fundet sted, og til mulighederne for at nye brud kan opstå. (Omkring årtusindeskiftet udkom derfor en række bøger om bl.a. Robespierre, Lenin og Mao). Ideologi blev nu i stedet for at være fornægtelsen af 'umuligheden af den ultimative sutur' til et libidinøst og ubevidst forehavende, der muliggør, at vi effektivt kan tilslutte os en ideologisk struktur, selvom vi udmarket ved, at samfundet er umuligt og ikke kan fuldendes. Den bevidste refleksive distance til en dominerende samfundsstruktur kan netop muliggøre en hemmelig tilslutning til den - som når progressive venstreorienterede 'går ind for' lighed og retfærdighed i verden og kritiserer deres egne politiske ledere for at være magtfuldkomne eller inkompetente og samtidig ikke desto mindre i deres arbejde og adfærd 'objektivt' tilslutter sig netop den politiske orden, som de kritiserer om aftenen over rødvinen. Ideologi fungerer som en tibetansk bedemølle: Den kan tro for én, mens man 'selv' holder sig lidt på afstand. Som Žižek udtrykte det i Astra Taylors portrætfilm Žižek! fra 2005, havde han efterhånden ændret sit syn på det liberale demokrati så meget, at han ville have anholdt sig selv, hvis han kunne gå tilbage til 1989.

Måske er denne gradvise forandring også en del af forklaringen på Žižeks stigende popularitet: Fra at være en skarp læser af Lacan og Hegel og en del af opgøret med det 20. århundredes totalitære ideologier er han blevet til en skarp læser af Lacan og Hegel, der analyserer de ideologiske systemer og 
mekanikker, som 'vi selv' er en del af i den vestlige verden i dag. Man bliver i en vis forstand simpelthen analyseret, når man hører eller læser Žižek. Undervejs blev han derfor til en mere og mere efterspurgt foredragsholder og skribent, der på én gang skrev filosofisk tunge værker og analyserede helt aktuelle begivenheder med psykoanalysen som brækjern og dermed bestandig udfordrede sit publikums selvforståelse. ${ }^{2}$

Hvis det var Žižek, der pludselig blev en verdensstjerne, understregede han på sin side til gengæld lige fra starten af sin internationale karriere, at hans arbejde ikke havde været muligt og nærmest ikke gav nogen mening uden i sammenhæng med kollegerne i STP. I sin introduktion til The Sublime Object of Ideology fremhævede Laclau derfor, hvordan 'den slovenske skole', og altså ikke bare Žižek, repræsenterede "de vigtigste kendetegn ved de radikalt-demokratiske kampe i Østeuropa” (Laclau 1989: xi). Måske undervurderede Laclau dog i virkeligheden, hvad denne skole repræsenterede, og hvordan den fungerede. Dens sigte var meget bredere end at være del af et demokratisk oprør, og Žižek selv var mere forbundet med sine kolleger og deres fælles filosofiske dagsorden, end med den relativt snævre politiske agenda, Laclau repræsenterede. Det er rigtigt, at der i hjertet af STPs historie er et politisk opgør med det 20. århundredes politiske ideologier, og at dets medlemmer næsten aldrig skriver noget, der ikke også har en eller anden politisk dimension (man kunne næsten kalde dette den anden nødvendige betingelse for at tilhøre 'den slovenske skole'), men ikke desto mindre er dets projekt ubetvivleligt 'større' end det, vi almindeligvis forstår ved politik. Som Žižek med vanlig tæft har udtrykt det, er det lige før, han vil sige, at politikken er til for teoriens skyld (og ikke omvendt). Det, man forstår, når man har forstået en situation som omvæltningerne i Østeuropa i deres systematiske sammenhæng, er ikke bare spørgsmål om arbejde, profit og adgang til stemmeurnerne, men (også) om subjektivitet, frihed, væren og det reelle.

\section{Partiet}

Selvom det var Žižek, der i 1989 'brød igennem' og blev en international filosofisk notabilitet, og hans stjernestatus nærmest kun er vokset siden, så har han hele tiden insisteret på at være del af et kollektiv, som både har været en base for udviklingen af de idéer, han selv præsenterer, og samtidig rummer genuint filosofisk arbejde, som måske ikke har den samme karakter af eksplosivitet og underholdningsværdi, som hans egne tekster, men til gengæld behandler et filosofisk emne grundigt og seriøst, så virkelig indsigt og 
fremskridt produceres. Op igennem 1980erne var denne kreds temmelig bred og talte også forbindelser til andre intellektuelle som kunstnere, musikere, sociologer og forfattere, og lidt paradoksalt kunne man næsten sige, at skolen blev opløst, idet den blev grundlagt. Den var et afsøgende og kritisk fællesskab med en række fælles interesser og positioner, men uden en sammenhængende doktrin, og især efter at den blev erklæret for en egentlig 'skole' begyndte dens medlemmer at spredes og divergere. Med The Sublime Object of Ideology, hvor Laclau identificerede den 'slovenske skole', var der sket et gearskifte, der ret hurtigt fik Žižek til at skille sig en del ud fra de fleste andre slovenske filosoffer, og der opstod en anden dimension i 'skolens' arbejde. Hvad der før hovedsaligt var en internt slovensk bevægelse, blev bredt ud til især USA og en række andre lande, og kritikken og emnerne skiftede i nogen grad fra at være mere regionalt til at være mere internationalt funderede.

Man kan med nogen ret opregne en akse igennem hele perioden fra 1971 til i dag omkring Žižek og Dolar, mens andre har været centrale personer undervejs. Lidt groft sagt kunne man sige, at Rastko Močnik, som tredjemand, repræsenterede den meget politiske del af halvfjerdserne, Rado Riha etableringen af den mere filosofisk-teoretiske del med STP, og Alenka Zupančič siden midten af halvfemserne den nuværende arbejdsdeling mellem Žižek som international filosof og debattør og Dolar og Zupančič som mere afdæmpede og lidt mere traditionelle tænkere i et parti, der deler helt grundlæggende filosofiske overbevisninger om psykoanalysen og den tyske idealisme. Žižeks bog om Irak-krigen (The Borrowed Kettle) fra 2004 var dedikeret til "Alenka Zupančič og Mladen Dolar - de to andre medlemmer af min partitrojka", og de tre har ved en række lejligheder, især i USA, turneret med foredrag om ét eller andet tema, som regel forbundet med Hegel og Lacan. I de senere år har Žižek selv refereret til 'den slovenske skole' eller 'Ljubljana-skolen' ved eksplicit at henvise til denne trojka. De tre er det tætteste, skolen har været på at etablere sig som en egentlig fælles filosofisk position, men igen er det en smule akavet at bruge selve termen 'skole'. Der er snarere tale om en teoretisk, politisk og personlig solidaritet, der udmønter sig i et produktivt arbejdsfællesskab mellem lige præcis disse tre tænkere. De har ikke elever og skriver ikke manifester, men de har ikke desto mindre en klar fornemmelse af, hvori solidariteten består, og hvordan den udøves.

En enkelt anekdote kan illustrere dette: Da denne artikels forfatter var på besøg som ph.d.-studerende i Ljubljana i 2005 og havde forelagt et udkast til en artikel for Zupančič, fik jeg at vide, at det alt sammen var udmærket, men hvis jeg ville optages i partiet, måtte jeg ændre min forstålse af Lacans be- 
greb om nydelse (jouissance). ${ }^{3}$ Det var ikke ligegyldigt, om man brugte den sene eller den tidlige Lacan, om man forstod det kategoriske imperativ hos Kant som en regulativ idé eller en traumatisk 'lov om det ukendte' osv. osv. Skolen, eller nu rettere partiet, havde en mening om det, og der var skabt en fælles tilgang til den tyske idealisme og psykoanalysen, som måske nok ikke var skrevet ned $i$ et manifest, men som alligevel ubetvivleligt cirkulerer blandt partiets medlemmer. Selvom partiet således formentlig er det mest sammentømrede, der har eksisteret i 'den slovenske skoles' historie, er heller ikke dette parti særligt let at lokalisere. I en årrække mødtes de tre simpelthen på restauranten Slon midt i Ljubljana for at diskutere, og deres fælles aktiviteter har i det hele taget bestået i en slags filosofiske venskaber med en fælles grundorientering, men uden hverken elever eller forskningsprogrammer.

Det er altså med god grund, at dette temanummer rummer introduktioner til Žižek, Dolar og Zupančič, for det er de tre, der udgør det fraværende centrum for den slovenske skole i dag. Også i Slovenien er Žižek en stor stjerne, og der er naturligt nok enorm interesse, når han deltager i debatter eller holder foredrag. Hans to kolleger er også meget velkendte figurer. Dolar er omgærdet af en ekstraordinær respekt blandt intellektuelle i Slovenien og er en slags omvandrende filosofisk leksikon - en klassisk dannet europæisk filosof, der kan udrede grundlagsproblemer i enhver videnskab og diskutere detaljer i værker inden for film, billedkunst, litteratur og poesi med den største lethed. Hans måde at skrive på er markant forskellig fra Žižeks, idet han som oftest vælger et emne (stemmen, forholdet mellem Hegel og Freud, psykoanalysens grundlagsproblemer...), holder sig til det og beskriver det i alle de aspekter, der kan have filosofisk relevans. Dolar og Žižek er begge systematiske tænkere, men hvor systemet nærmest skal rekonstrueres af læseren i Žižeks værker ud af utallige anekdoter og populærkulturelle referencer, er Dolar en mere traditionel filosof, der udfolder sit argument i en historisk og systematisk grundighed, der fremskriver overblikket, mens skriften udfolder sig.

$A$ Voice and Nothing More begynder f.eks. karakteristisk nok med en elaboreret udlægning af Walter Benjamins berømte anekdote fra de historiefilosofiske teser om en skakmaskine med en mekanisk dukke, der altid vandt over enhver menneskelig modstander, fordi der i virkeligheden sad en dværg indeni og styrede dukkens hænder gennem et system af spejle og snore. Denne historie er ofte blevet benyttet af Žižek (f.eks. i bogen The Puppet and The Dwarf), og Dolar indrømmer derfor "[næsten at være] flov over at besøge den igen" (Dolar 2006: 5). I stedet for blot at fortælle anekdoten og bruge 
den til at illustrere én eller anden pointe ("i dag må marxismen være den skjulte dværg, der styrer teologiens hænder", som Žižek ville sige), forfølger Dolar imidlertid historien i dens historiske sammenhæng og gør en elegant pointe ud af, at denne skakspillende maskine, der blev konstrueret af Wolgang von Kempelen i 1769, blev ledsaget og på mange måder overgået af en maskine af samme opfinder, der frembragte en stemme, der på en uhyggelig måde mindede om den menneskelige. Ved at folde historien helt ud og sammenligne de to maskiner, samtidig med at von Kempelens egne overvejelser om dem bliver bragt i spil, får Dolar fortalt en fortælling, der lægger præcist og omhyggeligt op til den følgende bogs tema. Mens skakmaskinen var en gåde og byggede på en illusion, var den talende maskine uhyggelig i den bedste freudianske forstand: Den frembragte en menneskelignende stemme ved hjælp af rent mekaniske midler, som enhver åbent kunne inspicere indefra og udefra uden at miste forundringen; som en effekt uden nogen tydelig årsag. Den talende maskine skulle egentlig bare introducere skakmaskinen, men netop denne introduktion, selve det at noget kunne introduceres af en maskine med en menneskelignende stemme, var hele optrinnets grundlæggende magiske effekt. En stemme, der syntes at komme ud af ingenting skabte betingelserne for, at noget overhovedet kunne opfattes som meningsfuldt, gådefuldt og overraskende.

Det samme kan siges om menneskets 'virkelige' stemme: Den kommer derindefra et sted, men den rummer ét eller andet mere, som hele tiden undslipper os, uanset hvor nøje vi betragter vores anatomi, tanker, meningsproduktion osv. Stemmen er os selv og samtidig noget andet; det er nogle gange som om, den taler 'af sig selv' og vi nærmest kan høre os selv udefra: "Hvem er det, der taler i mig?" Ved at udfolde historien om von Kempelen lykkes det Dolar at give rammerne for netop den pointe, han udfolder gennem resten af bogen. Historie, kultur og filosofi i én sammenhængende tankerække, der udtrykker en af de mest grundlæggende tanker i den antihumanistiske opfattelse af mennesket: At vi er fremmede for os selv, rummer noget 'mere end' os selv, aldrig er helt på højde med os selv osv.

Samme metode og grundlæggende antihumanistiske udgangspunkt finder man hos Zupančič, der også formår at genlæse velkendte historier og tekster på måder, der får læseren til at undres over, at han ikke har tænkt på det problem på denne måde før. Žižek giver i sit forord til Zupančič første større værk, der er en omarbejdet version af hendes ph.d.-afhandling fra sidste halvdel af 1990erne ${ }^{4}$, én af de fornemste hædersprisninger af denne evne, man næsten kan forestille sig. 
For en filosofisk kollega er det eneste tegn på virkelig respekt hadefuld misundelse - hvordan kan det være, at jeg ikke kom på det, forfatteren siger? Ville det ikke være rart, hvis forfatteren var faldet død om, inden hun havde skrevet dette, så hendes resultater ikke havde forstyrret min selvtilfredse fred? (Žižek 2000: xiii)

Det respektfulde had har siden ført Žižek og Dolar til at betragte Zupančič som én af partiet. Hendes fortolkninger af den klassiske filosofiske tradition er på en måde næsten mere żiżekianske end Žižek selv, fordi hun - som Dolar - udfolder sine pointer mere systematisk og vedholdende og samtidig både filosofisk og politisk er mere radikal end de to andre. I bogen, Ethics of the Real, kendetegner hun den etiske handling som en handling, der er en "hovedløs subjektivering" med et udtryk fra Lacan (Zupančič 2000: 104). Handlingen er det, der pludselig river os ud af vores almindelige etiske og konventionelle liv, og som derfor ikke kan følge nogen manual eller forskrift, bortset fra det kategoriske imperativs ubønhørlige krav om at handle således, at man kunne ville, at maksimen for ens handling blev almen lov. Ved at bringe Kant og Lacan sammen lykkes det Zupančič at skabe en form for antihumanistisk etik, dvs. en etik, der ikke handler om at gøre det, man selv umiddelbart ønsker eller har lært, men om at handle på et radikalt og uudgrundeligt bud, der på en måde virker bag på ryggen om én, når man handler etisk.

Igen er den umiddelbart urovækkende pointe, at menneskets særkende, nu endda som moralsk væsen, er, at det rummer noget 'mere end sig selv'; noget der undslipper dets bevidste kontrol, men som ikke desto mindre er det, det hele drejer sig om. Det, der virkelig er værd at kæmpe for, i arven fra Kant, er således ikke så meget forpligtelsen på en autonom fornuftlovgivning, der gør os i stand til at give gode grunde og beregne, hvilken handling, der vil være den rigtige at udføre i en given situation, men næsten tværtimod at der er noget ved en enhver virkelig handling, der har fortjent denne betegnelse, at den overstiger det, vi overhovedet kunne forestille os og beregne. Det 'reelles etik' handler således om at klargøre, hvorledes noget storartet pludselig kan ske, som vi end ikke kunne have forestillet os. "Det Reelle som det umulige betyder, at der ikke er noget rigtigt tidspunkt og sted for det; ikke at det ikke kan ske”, som det senere hedder (Zupančič 2003: 176). Zupančič har, udover Kant og Lacan, skrevet systematiske undersøgelser af Nietzsches filosofi (The Shortest Shadow, MIT Press, 2002) og komediens væsen (The Odd One In, MIT Press, 2008) - den sidste i øvrigt en bog, hun var fræk nok til i den slovenske original at kalde "Poetikken, Anden Bog", med en slet skjult henvisning til den berømte manglende anden halvdel af Aristoteles' poetik. 
Fælles for 'partiets' læsninger er, at de skaber en række 'kortslutninger' og skæve vinkler på klassiske filosofiske problemstillinger og tænkere ved at bringe den lacanianske psykoanalyse i spil som brækjern og game changer. Især to bogserier har indtil videre udfoldet denne ambition, begge med Žižek som redaktør, og deres forord giver ganske gode pejlinger på, hvordan det oprindelige 'slovenske' projekt stadig holdes i ave og, kunne man sige, langt fra endnu er udtømt. I serien Wo Es War på Verso, (et navn, der alluderer til Freuds berømte erklæring om, at "hvor Det/Id var, skal der blive Jeg"), hedder det således:

Seriens præmis er, at den eksplosive kombination af lacaniansk psykoanalyse og den marxistiske tradition detonerer en dynamisk frihed, der gør det muligt for os at sætte spørgsmålstegn ved selve grundantagelserne for kapitalens kredsløb. (F.eks. Žižek 2004: kolofonen)

Wo Es War er en slags radikalfilosofi-serie, hvor lacanianisme og marxisme er eksplicit kædet sammen som det metodiske omdrejningspunkt. Ved hjælp af psykoanalysen er det muligt at fremlæse fornyede pointer i den klassiske filosofi og dermed skabe grobunden for nye måder at se mennesket, samfundet, historien på. Den eksplosive cocktail skal med andre ord kastes ind midt i den fredelige, liberalt-demokratiske selvforståelse i tiden efter Murens fald, så vi kan se nye åbninger i stedet for den hastigt udbredte accept af 'historiens afslutning,' og det var om noget Žižeks og kumpanernes ambition at fortsætte med ideologikritiske og politiske læsninger, nu rettet mod 'den vestlige verden', snarere end mod de gamle, mere eller mindre totalitære systemer, som de selv havde været med til at gøre op med. Måske er det metaforen om det 'eksplosive' og om et 'kredsløb', der også ligger bag den efterfølgende serie på MIT Press, der fik overskriften "Kortslutninger" (Short Circuits), selvom man også bemærker, at den meget eksplicitte politiske ambition efterhånden er trængt mere i baggrunden. Selvom selve det sprængfarlige for så vidt er trængt helt frem til seriens titel, er ambitionen tilsyneladende bredere. $\mathrm{Nu}$ hedder det blandt andet:

Seriens underliggende præmis er, at den lacanianske psykoanalyse er et privilegeret instrument for en tilgang, hvis formål er at opklare en standardtekst eller en ideologisk formation og gøre den læselig på en helt ny måde. Den lange historie af lacanianske interventioner i filosofi, religion, kunst (fra de visuelle kunstformer til filmen, musik og litteratur), ideologi og politik, retfærdiggør denne præmis. (F.eks. Zupančič 2008: x.) 
Man kan ikke uden videre opdele de to bogserier i 'politiske' og 'filosofiske' bøger, men måske er den lidt bredere beskrivelse af formålet med STP-tilgangen i den anden bogserie alligevel et udtryk for, at der faktisk er tale om en mere gennemført filosofisk ambition i dag, som først rigtigt har befæstet sig med de tre nuværende 'medlemmer' af den slovenske skole (de er også alle tre nu anført som redaktører på Short Circuits-serien). Nuanceforskellen i de to forord kunne fortolkes som et udtryk for, at 'skolen' faktisk er blevet åbnet mere op - både mod en mindre eksplicit politisk dagsorden og mod andre kolleger rundt omkring i verden. I Short Circuits har således f.eks. italienske Lorenzo Chiesa (Subjectivity and Otherness, 2007) og rumænske Anca Parvulescu (Laughter, 2010) bidraget. Skolen er nu på én gang endegyldigt etableret... og mere på vej end nogensinde mod at åbne sig for hele verden og nye generationer.

\section{The End}

I skrivende stund er Ljubljana-trojkaen, partiet Dolar-Žižek-Zupančičc, i gang med at indsamle bidrag til en engelsksproget antologi om og med den nye generation af slovenske tænkere. En række af yngre talenter er ved at spire frem, som både kan siges at følge i sporene af de tre store og deres kolleger og forgængere og samtidig følge deres egne veje. Endnu et kendetegn ved den slovenske skole som en skole, der ikke holder op med ikke at etablere sig, er således, at dens 'elever' meget sjældent lever helt op til de dogmer, der mere eller mindre entydigt er etableret iblandt trojkaens tre, og man mærker ganske tydeligt på de mere etablerede, at denne forskydning eller skævhed passer dem ganske godt. Måske er betingelsen for at blive optaget i partiet i dag, at man samtidig fastholder en vis distance til det - at man lader sig inspirere, følger de spor og erfaringer, der er lagt ud, men ikke forsøger direkte at gentage de bevægelser, som allerede er blevet gjort. (Som Groucho Marx sagde det: "Jeg ville aldrig være medlem af en forening, der ville acceptere mig som medlem"). De mest talentfulde og selvstændige tænkere i den nye generation er en slags elever af de 'tre gamle', men ingen af dem er proselytter, der bare udfører detailopgaver - som en frankfurterskoleelev, der løser en konkret opgave for professor Habermas, eller som Gilbert Ryles sprogfilosoffer i 1950ernes Oxford, der blev sat i gang med at løse de 'vel ca. 1.000 filosofiske problemer', der findes, efter en grundanvisning i logisk-semantisk analyse. ${ }^{5}$

Man kommer ikke udenom, at der i dag er en kerne af tre, der identificerer sig som et filosofisk fællesskab, og som i øvrigt ikke føler sig forpligtet på 
at samordne sig med eller diktere noget for nogen andre. Der er stadig tænkere i forbindelse med disse tre, som mange ville betegne som en del af den slovenske skole (Renata Salecl, Peter Klepec, Miran Božovič, Rado Riha), men forbindelserne er i dag mere historiske og pragmatiske end de er decideret programmatiske. Samtidig er altså som sagt efterfølgerne for det meste, på forskellige måder, en smule uden for den allermest centrale dogmatik, der handler om at læse den tyske idealisme med Jacques Lacan. Nogle er mere hegelianere (som Jurij Simoniti og Aleš Bunta), nogle mere strukturalister (som Katja Kolšek), nogle mere rendyrkede psykoanalytiske tænkere (som Ana Žerjav og Samo Tomšič). Det kunne således næsten fortolkes symbolsk, at ét af de yngre talenter, filosoffen Tadej Troha, i sommeren 2011 påbegyndte et nyt projekt med titlen "The End": Måske indvarsler den nye generation allerede afslutningen på den skole, der aldrig rigtig nåede at etablere sig selv som skole. På den anden side er det mest karakteristiske ved den slovenske skole måske simpelthen netop, at den aldrig rigtig bliver en skole. At den ikke etablerer sig. Den har måske hele tiden snarere været en begivenhed i tænkningen end en skoledannelse; en begivenhed, der bliver ved med at melde sig i stadigt bredere kredse, men som aldrig rigtig bliver opsamlet og forløst i én endegyldig forklaring af, hvori dette særlige slovenske greb på filosofien består.

Det er selvfølgelig ikke tilfældigt, at denne artikels titel er en parafrase over Lacans berømte definition af det seksuelle forhold som et forhold, der "ikke holder op med ikke at indskrive sig" (Lacan 1975: 176). Det seksuelle forhold findes ikke, siger Lacan, dvs. der findes ikke nogen problemfri og harmonisk forening af kønnene, men det betyder ikke bare, at det ikke er, for netop det, at der ikke er en harmonisk og problemfri løsning på kønnenes forhold, betyder uendeligt meget for menneskene. Det seksuelle forhold er dét, det hele handler om, og derfor sætter det, at det på en bestemt måde ikke kan realiseres, sig igennem i alle vores liv på tragiske, komiske, traumatiske og jublende måder. Det er ikke på en måde, som bliver ved med at indfinde sig - netop som det, at det "ikke holder op med ikke at indskrive sig", fordi det bliver ved med at have afgørende vigtig betydning. Man kunne godt sige noget lignende om den slovenske skoles effekt. Siden Ernesto Laclau eftersøgte den, har en række forskere, journalister og filmskabere fra mange lande forsøgt at finde det sted, hvor skolen hører hjemme: En bygning, en doktrin, et manifest. Men den er der ikke; den kan ikke betragtes og beskrives, som man beskriver en bygning eller en stol eller en bog. Alligevel har den fået en enorm filosofisk effekt igennem forskelligartede filosofiske projekter og møder, hvor den 'oprindelige indsigt' om en produktiv kombination af psy- 
koanalyse og klassisk tysk filosofi udfolder sig. I disse sammenhænge bliver den ved med ikke at indskrive sig som en skole. At kalde den slovenske skole for en skole, der "ikke holder op med ikke at etablere sig", er med andre ord ikke en nedgradering af dens betydning; tværtimod: Kun det, der er vigtigt nok til at blive ved med ikke at etablere sig, bliver ved med at virke og skabe fornyelse og betydning.

Tadej Trohas projekt om "The End" er dog også karakteristisk på en anden og lidt mindre fortænkt måde: Det udtrykker en tendens, der har etableret sig blandt en række af de slovenske tænkere, til at behandle et tema, et begreb eller et fænomen gennem et helt værk og på måder, som ingen rigtig har gjort det før. ${ }^{6}$ Mladen Dolar har som sagt skrevet om stemmen og Alenka Zupančič om komedien, og derudover har Renata Salecl skrevet om valget, Aleš Bunta om dumheden, Slavoj Žiżek om vold og Tadej Troha om mirakler. Det er sågar i visse kredse ${ }^{7}$ blevet almindeligt at betegne noget som en 'slovensk bog', når et værk baserer sig på netop dette greb med at gennemgå alt relevant materiale om en lidt overraskende problemstilling for at give den en ny filosofisk fortolkning. Afslutningen, som muligvis kan anes gennem de nye tænkere, der ikke uden videre søger om optagelse i partiet, og måske heller ikke ville få det, er således måske samtidig indvarslingen af en ny begyndelse, der allerede et stykke tid har været i gang. En bredere vifte af tænkere er igen begyndt at tegne sig, som markerer en ny fase i den slovenske skoles historie.

Måske kunne man illustrere skolens historie ved en sammenligne den med en timeglasform: I toppen hele bevægelsen omkring opbruddet i Østeuropa og afsøgningen af den franske strukturalisme som et helt nyt grundlag for en marxistisk filosofi. I midten, på det smalleste sted, de tre elefanter i partiet Dolar-Žižek-Zupančič, som har udviklet en egentlig fælles filosofisk position. Og i bunden den nye bredde, der bygger på de foregående 40 års arbejde, men igen manifesterer sig i mere forskelligartede og mindre entydigt skoledannende projekter.

Skulle man lave en slags sociologisk opsummering af, hvad der kendetegner de tænkere, der i dag deler tilstrækkeligt mange familieligheder til at blive associeret med det, vi almindeligvis kalder den slovenske skole, kunne man forsøge sig med følgende: Et prototypisk medlem af den slovenske skole er velfunderet i fransk strukturalisme, tysk idealisme og lacaniansk psykoanalyse, skriver om et væsentligt, men lidt underbelyst emne ved at kortslutte den almindelige eller traditionelle forståelse af det på en måde, der rummer interessante politiske perspektiver og bidrager til den antihumanistiske 
marxisme, og publicerer på Problemi i Ljubljana. Hvis pågældende medlem ikke hedder Žižek, Dolar eller Zupančič, ser det sig dog formentlig lige nøjagtig ikke så meget som medlem af skolen, at denne kan etablere sig på det.

\section{Noter}

1 Denne artikel er resultatet af en rejse til Ljubljana fra den 10. til den 19. juli 2011 og er for en stor dels vedkommende baseret på interviews og diskussioner af den slovenske skoles historie og status med Mladen Dolar, Eva Bahovec, Aleš Bunta, Alenka Zupančič og Tadej Troha. Jeg er dem alle stor tak skyldig.

2 Som Lilian Munk Rösing har sagt det, var der i tiden omkring karikaturkrisen i Danmark i 2005 og 2006 ikke så få Žižek-læsere, der længselsfuldt ventede på, hvad den store slovener ville sige om krisen, så vi selv kunne forstå, hvad der var foregået i vores land. (Da dén analyse kom, var der dog en del, der blev en smule skuffede).

3 Artiklens version var for rigid og en revisionistisk udgave af nydelse, der førte tilbage til den tidlige Lacan, mens partiets opfattelse var, at jouissance, frem for at være et umuligt, uopnåeligt punkt for det menneskelige begær, er en allestedsnærværende realitet; en virkelighed, som man ikke uendeligt stræber efter, men tværtimod aldrig kan komme af med.

4 Et ph.d.-arbejde, der foregik i Ljubljana og Paris, med ingen ringere end Slavoj Žižek og Alain Badiou som vejledere.

5 Denne påstand om Gilbert Ryle er baseret på John Searles fortælling under et foredrag i Aarhus i midten af halvfemserne.

6 I Trohas tilfælde en idé om at behandle 'afslutningen' via tre forskellige instanser af den: Filmens konklusion i det berømte "The End"; psykoanalysens afslutning og filosofiens afslutning.

7 Kredsene omkring Center for Vild Analyse.

\section{Litteratur}

Chiesa, Lorenzo (2007): Subjectivity and Otherness - A Philosophical Reading of Lacan, Massachusetts: MIT Press.

Dolar, Mladen (2006): A Voice and Nothing More, Massachusetts: MIT Press.

Lacan, Jacques (1975): Encore - The Seminar of Jacques Lacan, Book XX, New York: W.W. Norton.

Laclau, Ernesto \& Mouffe, Chantal (1985): Hegemony and Socialist Strategy, London: Verso.

Laclau, Ernesto (1989): “Preface” i Slavoj Žižek: The Sublime Object of Ideology, London: Verso, s. ix-xi.

Parvulescu, Anca (2010): Laughter - Notes on a Passion, Massachusetts: MIT Press. 
Žižek, Slavoj (1989): The Sublime Object of Ideology, London: Verso.

Žižek, Slavoj (2000): “Foreword: Why is Kant Worth Fighting For?” i Alenka Zupančič (2000): Ethics of the Real, London: Verso, s. vii-xiii.

Žižek, Slavoj (2003): The Puppet and the Dwarf, Massachusetts: MIT Press.

Žižek, Slavoj (2004): The Borrowed Kettle, London: Verso.

Zupančič, Alenka (2000): Ethics of the Real, London: Verso.

Zupančič, Alenka (2003): The Shortest Shadow - Nietzsche's Philosophy of the Two, Massachusetts: MIT Press.

Zupančič, Alenka (2008): The Odd One In, Massachusetts: MIT Press. 
